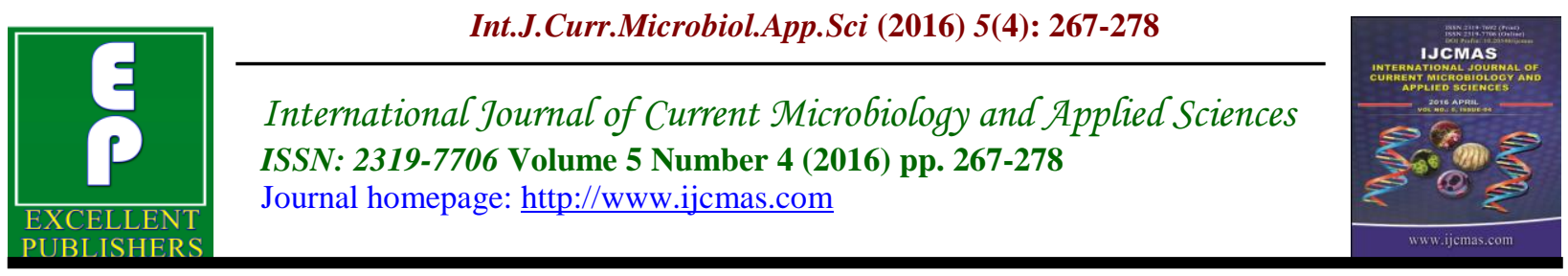

Original Research Article

http://dx.doi.org/10.20546/ijcmas.2016.504.031

\title{
Effect of Co Fermentation on Nutritional and Sensory Evaluation of Bitter Yam and Cowpea as Complementary Food
}

\author{
Oyarekua Mojisola Adenike* \\ Federal University Oye (FUOYE), Microbiology Department, P.M.B 373, Oye-Ekiti, Nigeria \\ *Corresponding author
}

\section{A B S T R A C T}

Keywords

Co-Fermentation,

Bitter-Yam,

Cowpea,

Infants,

Nutrients,

Microorganisms

\section{Article Info}

Accepted:

15 March 2016

Available Online:

10 April 2016
Fermented sliced yellow bitter yam and cowpea grains in ratio 70:30 (A), $60: 40$, (B) were co-fermented an aerobically for $72 \mathrm{~h}$ at room temperature. Controls (C) and (D) were unfermented and in same ratio as the co-fermented samples All samples were subjected to microbial, biochemical, consistency, nutritional and anti-nutritional factors and organoleptic evaluation using standard methods. The $\mathrm{pH}$ reduced rapidly at $24 \mathrm{~h}$ from $6.8-6.0$ gradually to 5 by $72 \mathrm{~h}$; total titratable acidity increased gradually during this period. Microbial counts decreased as fermentation progressed to 72hours. Organoleptically, cofermented samples scored higher in general acceptability and unfermented samples higher than the co-fermented in terms of colour, aroma, taste and texture. Sample A had the highest value of vit. A. Samples C and D (60:40 mixtures) had the highest values sodium, potassium, manganese and calcium indicating that ratio of the tuber and legume may play an important role in the content of extractable minerals in the mixture.

\section{Introduction}

About 13 million of infants and children under five years of age die annually due of malnutrition Ojofeitimi (2007). In Nigeria, cereal-based traditional infant complementary foods are inadequate to meet daily nutrients and energy requirements of infants while formula foods are too expensive for low socio-economic status mothers Oyarekua (2013). Trifoliate yam Dioscorea dumetorum is called bitter because it consists of water soluble alkaloids dihydrodioscorine. Dihydrodioscorine can cause paralysis of the nervous system but can also be dissipated by soaking and boiling (Degras, 1993). In Nigeria, the tubers are boiled with the peel after which the peel is removed and eaten as boiled yam. Nigeria accounts for $61 \%$ of production of cowpea (Vigna unguiculata) in Africa and 58\% worldwide (Davis, 2013). Nutritionally, cowpea contains protein, major minerals and small amounts of iron, sodium, zinc, copper, manganese, and selenium and vitamins. 100 grams of Cowpeas have 44 calories. (Alice, 2010).

Fermentation is an ancient method of food processing and preservation. Most food 
substrates for fermentations have heterogeneous physicochemical composition thus the

Simultaneous occupation of multiple microorganisms (Paredes-López \& Harry, 2006). Lactic acid spontaneous fermentation involves mainly lactic acid bacteria (LAB) which by their metabolic activity can utilize substrates sugars to produce organic acids and other metabolites that will give desirable products for human consumption. Studies on co-fermentation of bitter yam tuber and legumes as infant complementary food are rare. The objective of this study was to determine the effect of co-fermentation on the nutritional Sensory attributes status of co-fermented bitter yam and cowpea in two different ratios, as infant complementary food.

\section{Materials and Methods}

The study was conducted in Nigeria in the laboratories of a Federal University OyeEkiti and Institute of Science and Laboratory Technology all in Nigeria.

\section{Samples Preparation}

Bitter yams tubers were washed with distilled water to remove the sand, cowpea grains were picked to remove stones. The bitter yam was peeled, sliced and $70 \mathrm{~g}$ weighed with $30 \mathrm{~g}$ of cowpea (A). Another $60 \mathrm{~g}$ portion of bitter yam was also weighed with $40 \mathrm{~g}$ of cowpea (B). Each mixture was immersed in $300 \mathrm{ml}$ of distilled water and left to ferment for $72 \mathrm{~h}$ at $30^{\circ} \mathrm{C}$. At every $24 \mathrm{~h}$ of fermentation time, $\mathrm{pH}$ and microbial status were evaluated. After $72 \mathrm{~h}$, each mixture was wet milled sieved, allowed to further ferment for $24 \mathrm{~h}$, dewatered and sediment dried at $60^{\circ} \mathrm{C}$ for $48 \mathrm{~h}$, milled and sieved to fine flour using $300 \mathrm{mmm}$ sieve. The remaining unfermented samples $(\mathrm{C}$ and
D) served as the control.

$\mathrm{pH}$ changes over $72 \mathrm{~h}$ fermentation time were measured according to AOAC 2005.

Sensory evaluation: Was done using Thirteen (13) mothers from a local crèche was carried out to determine the taste, texture, color, Aroma, and acceptability of products gruels by making use of 9-point hedonic scales as described by Ihekoronye and Ngoddy (1985). Respondents were made to abstain from tasting anything an hour prior to the evaluation. Two spoonfuls of boiled gruel of A, B, C and D were dished into a transparent plate so as not to affect the color scoring of the gruels. Each mother was provided with a spoon, serviette paper, and cup of water to rinse their mouths to prevent the taste of one gruel from affecting the other. Sensory Evaluation Form was provided for each respondent.

Antinutritional factors: Phenols, Phytate/phytic acid, Tannins, Cyanide and Phytin were determined according to AOAC (2005).

Mineral Safety index: The standard Mineral Safety index for minerals for infants are $\mathrm{Na}$ (4.8), mg (15) P (10) Ca (10), Fe (6.7) and Zn (33), (Whitney, Hamilton and Rolfes 1990.)

Calculation: Tabulated Mineral Safety Index $\mathrm{X}$ Value of Mineral in Sample $=$ MSI

Recommended Mineral Safety Index For Infants (Whitney and Hudson)

Carotenoid analysis was carried using the method of Rodriguez-Amaya and Kimura (2004). This involved extraction with cold acetone using a mortar and pestle, partitioned to petroleum ether and taking the absorbance at $450 \mathrm{~nm}$. 
Consistency: Was determined using Bostwick Consistometer as modified by Oyarekua (2011). The distance the gruel covered in 30seconds on the Consistometer was measured as consistency reading (i.e. flow in $\mathrm{mm} / 30$ seconds).

Proximate Composition: The levels of moisture content, crude fibre, crude protein and lipid content were determined according to AOAC (2005). Carbohydrates were obtained by difference. All samples were analyzed in triplicates. Dry matter was estimated by difference of moisture content.

Minerals Determination: The mineral contents were determined according AOAC (2005) using atomic absorption spectrophotometer (GBC Scientific Equipment Pty Ltd).

\section{Statistical Analysis}

Statistical analysis was performed using SPSS-21 (Statistical Packages for Social Sciences- version 21). Unpaired t-test was used to assess significant difference between means $\mathrm{P}<0.05$ was considered statistically significant.

\section{Results and Discussion}

Processing of trifoliate yam tubers into flour add longer term value to the tubers with a high nutritional potential (Medosa, et al., 2005, Sefa-Dedeh and Afoakwa 2001). Also, Aderiye and Ogunjobi (1998) reported that Pediococcus, Lactobacillus and Pseudomonas, Bacillus subtilis and two other Gram negative coccal cells were implicated in cooked fermented yam. Lactic acid bacteria generally grow readily in most food substrates and lower the $\mathrm{pH}$ rapidly to a point where competing organisms are no longer able to grow. In Fig.1 of this study, for samples co-fermented samples (A and
$\mathrm{B})$, the $\mathrm{pH}$ had rapid reduction at $24 \mathrm{~h}$ from 6.8 to 6.0 and reduced gradually to 5 by $72 \mathrm{~h}$. The rapid decrease within the first 24 hours in the $\mathrm{pH}$ of co-fermented mixture may be due to availability of more nutrients for microbial proliferation and enhanced metabolic activities, the presence of cowpea must have made the fermenting medium slightly alkaline in nature thus preventing the $\mathrm{pH}$ from further reduction to $\mathrm{pH} 4.0$ or below. Preservation of foods by fermentation depends on $\mathrm{pH} 4.0-5.0$; some microorganisms are active at $\mathrm{pH} 9.6$ and others at $\mathrm{pH} 3.2$.

The Recommended Daily Allowance in terms of nutrient densities (RDA) from infants complementary food referred to in this work was based on complementary food consumption of $275 \mathrm{ml} /$ day, $450 \mathrm{ml} /$ day for between 6-8months, 9-11months and 11-23 months old, respectively for low to high breast milk intake (WHO/UNU/FAO 1998).

The proximate chemical composition, Table 1 showed that the moisture content of unfermented analogues (12.87-11.54\%) were higher than those of their co-fermented (8.59- 9.93\%). The moisture content of samples in this study was too high to meet the recommended dietary allowance (RDA) for infants and babies, and also does not fulfill the requirement reported by protein advisory groups (PAG) (1971) for weaning food (Table..), this might be due to low drying temperature $\left(60^{\circ} \mathrm{C}\right)$ in the oven. However, the results of this study are similar with various reports (Elemo, et al., 2008; Ahmed, 2005). Moreover, the obtained result (8.05-8.13\%) was higher than Modu, et al., (2010) findings (3.37 - 4.50\%). However, moisture content can be reduced using roller dryer or drum dryer instead of oven. The ash content of the samples meets both the RDA1 and PAG2 requirements. 
The protein content increased more in sample A as seen in Table 1, the fat content of co-fermented sample with $70: 30 \mathrm{w} / \mathrm{w}$ ratio increased more than other samples. Fat in infants' food will increase the energy density as well as act as a transport vehicle for fat soluble vitamins needed for optimum growth in an infant (WHO/UNU/FAO, 1998).

The total carbohydrate content of all samples fulfills the RDA requirement for infant and babies. The carbohydrate content increased more in the ratios with higher bitter yam concentration (Table 1), this might be due to the high carbohydrate content from bitter yam therefore decreasing bitter yam amount in the formulation may decrease its content. Although sulphurcontaining amino acids are limiting in cowpea proteins, the values of proteins in all the samples (A, B, C, and D) exceeded the $14 \mathrm{~g} / 100 \mathrm{~g}$ protein recommended for complementary foods for 6-23 month old infants.

The results (Table 1) indicate that retinol content of the samples were too low to meet the RDA requirement. There is a correlation between VAD and protein malnutrition (PEM) because the transport of retinol across different organ is made possible by retinol-binding protein (RBP) (McClaren and Frigg 2001).

Co-fermented mixture had significantly $(\mathrm{P}<0.05)$ higher value of 10.0 and 5 $\mu \mathrm{RE} / 100 \mathrm{~g}$ in samples $\mathrm{A}$ and $\mathrm{B}$ respectively than their unfermented analogue of 2.5 $\mu \mathrm{RE} / 100 \mathrm{~g}$ in sample $\mathrm{C}$ to not detected level of sample D. (table 1). Yellow bitter yam is rich in carotene (mainly trans-beta-carotene) which might have been released during fermentation. The value of all the cofermented mixtures met the RDA for 11-23 months old; it might be desirable as a vitamin A source for infants but met $\mu \mathrm{g} R E$ for 1-3years, respectively and nutrient needs from complementary foods by level of usual breast milk intake in $\mu \mathrm{g} R E$ for average (13)

WHO/FAO/UNU 1998. From this study, sample A might meet the vitamin A need for 6-8 months based on average breast-milk intake.

Carotenoids: This finding is in agreement result is supported by Ismail, et al., (2000).

Vitamin A plays a role in improving utilization of iron for haemopoiesis and its liberation from iron stores. Retinol and / retinoic acid are required for the synthesis of the iron transport protein transferring (Devlin, 2006) according to Subharno, et al (1993), supplementation with iron and vitamin A can virtually eliminate nutritional anemia). The carotenoid value of all samples in this study was lower than RDA average value of $96.8 \mu \mathrm{gRE} / \mathrm{day}$ for 6-23months based on $750 \mathrm{ml} / \mathrm{d}$ the low In home traditional sun-drying, oxygen exclusion and low-normal temperature (like in fermentation) can cause carotenoid destruction (Rodriguez-Amaya 2002). The low carotenoid values of the samples in this study is in agreement to the finding of Ahmad (2001); who reported that fermentation reduce carotenoid content of carrot. Values might be due to carotenoid susceptibility to degradation during the heat treatment or the release of organic acids during fermentation process due to isomerisation from trans-carotenoids (normal configuration in nature) to ciscarotenoids might have occurred. (Della and Rodiquez 2002). According to Rodriguez Amaya (2004), Cis-isomers increased during heating of carrot juice.

Consistency: The flow is inversely proportional to the flour concentration 
because as the flour concentration increased, the consistency reduced Fig. 2. Also a high consistency value means low viscosity. A low viscous infant food is desirable because by implication, it means higher nutrient and energy densities (Oyarekua 2013). Fig. 2 also shows that at $10 \%$ flour concentration, sample $\mathrm{C}$ had a higher consistency value of $11.2 \mathrm{~mm} / 30 \mathrm{sec}$ followed by D and B while A had the lowest. This shows that $\mathrm{C}$ gruel at $10 \%$ might be easy for the infant to swallow and might contain more nutrient and energy densities than other mixtures at this concentration. This finding is in agreement with Oyarekua (2013). High energy density (ED) gruels depend on the flour concentration and nutrient contents therefore can improve infant's energy and nutrient intakes (Golden 2009).

The mean scores of different sensory parameters are given in Table 4. A statistical significant variation was observed among different samples regarding color, Flavor, taste and overall acceptability (as per DMRT at $5 \%$ significant level).

The highest score for color preference was observed in sample C (5.11), followed by D (5.10). The color variability between samples A and B which were statistically identical $(\mathrm{P}<0.05)$ to each other. The best score for flavor was found in samples $\mathrm{C}$ and $\mathrm{D}$ and were statistically identical $(\mathrm{P}<0.05)$ with the value of 5.90. While samples $A$ and B had 3.90 and 3.50 respectively. Sample D had the highest score for taste (6.80) followed by C 6.70 and B 4.90 while sample A had the lowest score of 4.11. C and D had comparable values in terms of color, texture, flavor and overall acceptability. The best result of overall acceptability was found in samples A and B (with comparable values of 6.10 and 6.11respectively). Also, A and B were comparable in respect of color (Table 4). Lactic acid bacteria influence the flavor of fermented foods in the production of acid with attendant lowering of $\mathrm{pH}$ those results in increased sourness. All the sensory parameters suggested that samples a and B. The sensory parameters results also showed that mothers prefer the fermented sample to unfermented sample in terms of general acceptability.

Anti-nutritional factors: The study of Table 4 showed ANF values of the mixtures B and A had more total phenol than $\mathrm{C}$ and $\mathrm{D}$, which showed that co-fermentation of bitter yam and cowpea, did not effectively reduce anti nutrients. A higher physic acid content co-fermented B and C unfermented samples can be attributed to enhanced activity of the enzyme photoset and that of alpha-amylase which could lead to release of Calcium ion that can chelae with phytic acid to make it more available (Oyarekua 2013). Phytic acid is a strong inhibitor of iron absorption in both infants and adults; it inhibits pepsin, amylase and trypsin necessary for hydrolysis of proteins and starch in the small intestine Oyarekua and Bankefa (2015). The 72h pH of mixture $\mathrm{B}$ and $\mathrm{A}$ of 5.0 and 5.5 respectively (fig.1) were optimal for phytases activities as reported by Oyarekua and Bankefa (2015). This will make samples Aand B undesirable for infants.

Cyanide ions inhibit several enzymes systems; depress growth by interference with certain amino acids (Soetan and Oyewole, 2009). D had the highest value of cyanide followed by $\mathrm{C}$ then $\mathrm{A}$ and lastly $\mathrm{B}$ this indicate that fermentation process can reduce cyanide content. Phenols like phytates, bind important minerals thus resulting in their low availability. However since the toxic effect of anti-nutrients can be avoided if the food is fermented and cooked before consumption; the combination effect of fermentation and cooking in this study may reduce the effect of anti-nutritional 
factors to safe levels (Oyarekua, 2013). Tannins complex with iron and zinc thus inhibiting activities of microbial enzymes involved in fermentation of tubers like bitter yam while tannins in legumes like cowpea reduce ionisable iron absorption by acting as a natural iron chelating agent. Soaking in water during fermentation prior to cooking has a significant effect on reducing the tannin content $0.35-0.48 \mathrm{mg} / 100 \mathrm{~g}$ for samples A and B respectively especially when the water was discarded in this study (Oyarekua and Bankefa, 2015).

Minerals: Minerals Protein energy malnutrition is regarded as deficiency of some nutritionally important minerals which are components of key enzymes. The body uses mineral ions as electrolytes for regulation, distribution, composition and acidity of its fluids. Loss of minerals during the fermentation in ogi production was reported by (Akingbala et al., 1981). Table 2 shows the mineral composition of the samples. Mixture D had the highest Manganese value followed by $\mathrm{C}$ sample. Manganese a component of enzymes helps in proper functioning of the brain and spinal cord. Deficiency can lead to defective growth abnormalities, central nervous systems and disturbances in the way the body handles fats (Nieman, et al., 2002). The manganese levels in both samples met the RDA for 6-23 for infants at low to high breast milk intake (WHO/FAO/UNU.98). Consumption of any of the two samples might help in proper functioning of the spinal cord. Manganese is a component of key some enzymes. The values of all samples were significantly $(p=0>0.5)$ lower to the recommended daily requirement $(15.2 \mu \mathrm{g})$ for 11-23months old. (WHO/FAO/UNU.98).

Calcium is needed for bone and teeth formation. Deficiency of calcium leads to rickets in infant's unfermented mixtures $\mathrm{C}$ and $\mathrm{D}$ had the highest value of calcium, making them very rich in calcium. In this study the values of calcium decreased in cofermented mixture this is contrary to the finding of Oyewole and Odunfa (1990) that fermentation release bound calcium. However the values of all samples are higher than the calcium needs of (295) mg/d from complementary foods (WHO/FAO/UNU.1998) for ages 911 months (Average need based on daily consumption of $250 \mathrm{ml} / \mathrm{d}$ ); and for 11 23 months (based on daily consumption of $750 \mathrm{ml} / \mathrm{d}$ ). Iron is needed in blood cells formation proper growth and oxygen circulation the values of both minerals in this work might be desirable for infants of 911 months. In the values of sodium, potassium, manganese and calcium samples $\mathrm{C}$ and D (60:40). This shows that the ratio of the tuber and legume may play an important role in the content of extractable minerals in the mixture. However, in iron content, samples A and B had highest values of iron compared with their unfermented analogues this might indicate that fermenting microorganisms oxidized ferric ion in the substrate to ferrous ion during their metabolic activities thus increasing available iron. Deficiency of iron can be mild when iron store is low in the body but can be severe when low in the blood levels of hemoglobin resulting in anemia or the deficiency can also be extended if the iron is depleted from the iron store in the bone marrow and liver resulting in anemia. Iron deficiency anemia is also a risk factor for abnormal cognitive, depressed growth social development as well and neuronpsychomotor development.

Zinc it is a limiting factor in the growth of severely malnourished infants in developing countries due to diets low high in phytates. Deficiency of zinc may negatively affect the 
behavioral development and growth of infants. (WHO/FAO/UNU.98). Zinc also contributes to the synthesis of retinol binding protein (RBP) which is responsible for the transport of vitamin A (Livnyl et al., 2003). In this study, sample $C$ had significantly higher value than others while values of samples $A$ and $B$ were comparable. As shown in Table 2 the consumption of of A, B and D may lead to significant increase in the growth of 11-23 months infants Oyarekua (2009); because these values are comparable to British $(4.7 \mathrm{mg} / 100 \mathrm{~g})$ standard required from complementary foods for 11-23 months based on daily consumption of $750 \mathrm{ml} / \mathrm{d}$ (WHO/FAO/UNU.98) but lower than $10 \mathrm{mg} / 100 \mathrm{~g}$ required from supplementary foods for older infants and young children (CODEX 1991). The values of zinc in the sample $\mathrm{C}$ was higher than average RDA (4.7 British standard) and 2.08 Krebs's standards) from complementary foods for
11-23 months. However, the value in sample A, B and D were comparable to that of Krebbs standard.

In this study iron content is slightly higher in sample B than A both of which are significantly $(\mathrm{p}>0.05)$ than $\mathrm{C}$ and $\mathrm{D}$ However, excess iron can lead to iron poisoning in children (Adeyeye and Falaye, 2004). In this study iron value in samples $A$ and $\mathrm{B}$ were comparable to average RDA of $9.13 \mathrm{mg} / 100 \mathrm{~g}$ (medium breast milk intake) and that of sample D comparable to $5.8 \mathrm{mg} / 100 \mathrm{~g}$ (High breast milk intake) expected from complementary foods.

Infants needs about $10 \mathrm{mg} / 100 \mathrm{~g}$ of iron. The results obtained (Table 2) showed that the co-fermented samples were observed to be low in mineral contents compared to the unfermented samples this may be due to sieving and dewatering during fermentation process.

Table.1 Proximate Composition and Vitamin A Content of Co-Fermented Bitter Yam/Cowpea Mixture

\begin{tabular}{|l|l|l|l|l|l|l|l|l|}
\hline S/No & $\%$ Ash & $\% \mathrm{Mc}$ & $\% \mathrm{Cp}$ & $\%$ Fat & \%Fiber & $\% \mathrm{CHO}$ & $\begin{array}{l}(\mathrm{mg} / 100 \mathrm{~g}) \\
\text { Vit. A }\end{array}$ & $\mu \mathrm{RE} / 100 \mathrm{~g}$ \\
\hline A & 1.01 & 8.59 & 18.85 & 4.46 & 1.01 & 66.09 & 0.06 & \\
\hline B & 0.44 & 9.93 & 17.42 & 3.95 & 0.66 & 67.60 & 0.03 & \\
\hline C & 1.55 & 12.87 & 19.64 & 3.41 & 0.51 & 62.02 & 0.015 & \\
\hline D & 1.76 & 11.54 & 17.40 & 3.09 & 0.36 & 65.83 & ND & \\
\hline
\end{tabular}

KEY: A= Bitter Yam / Cowpea 70:30, B=Bitter Yam / Cowpea 60:40, C= Unfermented Bitter yam/Cowpea 700:300, BC= Unfermented Bitter Yam / Cowpea 60:40

Table.2 Mineral Composition of Co-Fermented Bitter Yam/Cowpea in Different Ratio and their Unfermented Analogues

\begin{tabular}{|l|l|l|l|l|l|l|}
\hline Sample & $\mathrm{Na} \mathrm{mg} / 100 \mathrm{~g}$ & $\mathrm{~K} \mathrm{mg} / 100 \mathrm{~g}$ & $\mathrm{Ca} \mathrm{mg} / 100 \mathrm{~g}$ & $\mathrm{Zn} \mathrm{mg} / 100 \mathrm{~g}$ & Fe $\mathrm{mg} / 100 \mathrm{~g}$ & $\mathrm{Mn} \mu \mathrm{g}$ \\
\hline $\mathrm{A}$ & 188.25 & 219.92 & 416.84 & 2.24 & 7.63 & 1.00 \\
\hline $\mathrm{B}$ & 325.15 & 463.21 & 490.63 & 2.26 & 8.52 & 1.28 \\
\hline $\mathrm{C}$ & 202.03 & 441.12 & 565.62 & 6.94 & 4.25 & 1.74 \\
\hline $\mathrm{D}$ & 438.36 & 513.72 & 717.82 & 2.86 & 5.76 & 2.24 \\
\hline
\end{tabular}

KEY: A= Bitter Yam / Cowpea 70:30, B=Bitter Yam / Cowpea 60:40, C= Unfermented Bitter yam/Cowpea 70:30, D= Unfermented Bitter Yam / Cowpea 60:40 
Table.3 The Mineral Safety Index of Co-Fermented Bitter Yam/Cowpea in Various Ratios and their Unfermented Analogues

\begin{tabular}{|l|l|l|l|l|l|l|l|l|l|l|l|l|}
\cline { 2 - 15 } \multicolumn{1}{c|}{} & Ca & \multicolumn{3}{l|}{ Fe } & \multicolumn{2}{l|}{ Na } & \multicolumn{2}{l|}{ Zn } \\
\hline sample & TV & CV & D & TV & CV & D & TV & CV & D & TV & CV & D \\
\hline A & 10 & 10.42 & -0.42 & 6.7 & 5.11 & 1.59 & 4.8 & 2.26 & 2.54 & 33 & 12.32 & 20.63 \\
\hline B & 10 & 12.27 & -2.27 & 6.7 & 5.71 & 0.99 & 4.8 & 2.42 & 2.38 & 33 & 38.17 & -5.17 \\
\hline C & 10 & 14.14 & -4.14 & 6.7 & 2.85 & 3.85 & 4.8 & 3.90 & 0.90 & 33 & 12.43 & 20.57 \\
\hline D & 10 & 17.95 & -7.95 & 6.7 & 3.86 & 2.84 & 4.8 & 5.26 & -0.46 & 33 & 15.73 & 17.27 \\
\hline
\end{tabular}

KEY: A= Bitter Yam / Cowpea 70:30; B=Bitter Yam/ Cowpea 60:40; C= Unfermented Bitteryam/Cowpea 70:30; D= Unfermeted Bitter Yam / Cowpea 600:400; TV= Tabulated value; $C V=$ Calculated value; $D=$ Difference between TV and CV

Table.4 Anti Nutrients Content of Co-fermented Bitter Yam/Cowpea Mixture in Different Ratio and their Unfermented Analogues

\begin{tabular}{|l|l|l|l|l|l|}
\hline Sample & $\begin{array}{l}\text { Tannin } \\
(\mathrm{mg} / 100 \mathrm{~g})\end{array}$ & Phytate $(\mathrm{mg} / 100 \mathrm{~g})$ & $\begin{array}{l}\text { Phytin- } \\
\text { P(mg/100g) }\end{array}$ & Phenol(mg/100g) & Cyanide(mg/Kg) \\
\hline A & 0.35 & 5.77 & 1.62 & 0.33 & 34.07 \\
\hline B & 1.40 & 12.40 & 3.44 & 0.36 & 31.48 \\
\hline C & 0.48 & 9.35 & 2.58 & 0.18 & 42.41 \\
\hline D & 0.51 & 7.75 & 2.12 & 0.24 & 48.34 \\
\hline \multicolumn{5}{|l|}{} \\
\hline \multicolumn{7}{|l|}{ Sensory Evaluation } & Taste & Aroma & Acceptability \\
\hline A & Color & Texture & $4.11^{\mathrm{a}}$ & $3.90^{\mathrm{b}}$ & $6.10^{\mathrm{a}}$ \\
\hline B & $4.40^{\mathrm{a}}$ & $6.10^{\mathrm{a}}$ & $4.90^{\mathrm{b}}$ & $3.50^{\mathrm{a}}$ & $6.11^{\mathrm{a}}$ \\
\hline C & $4.40^{\mathrm{a}}$ & $6.70^{\mathrm{b}}$ & $6.70^{\mathrm{c}}$ & $5.90^{\mathrm{c}}$ & $4.10^{\mathrm{b}}$ \\
\hline D & $5.11^{\mathrm{b}}$ & $7.40^{\mathrm{c}}$ & $6.80^{\mathrm{d}}$ & $5.90^{\mathrm{c}}$ & $4.12^{\mathrm{b}}$ \\
\hline
\end{tabular}

Key= Bitter Yam / Cowpea 70:30, B=Bitter Yam / Cowpea 60:40, C= Unfermented Bitter yam/Cowpea 70:30, D= Unfermented Bitter Yam / Cowpea 60:40. Values are in duplicates. Values with the same superscript are significantly comparable to each other

Fig.1 Changes during Co-Fermentation of Samples A and B Over 72h Fermentation Time

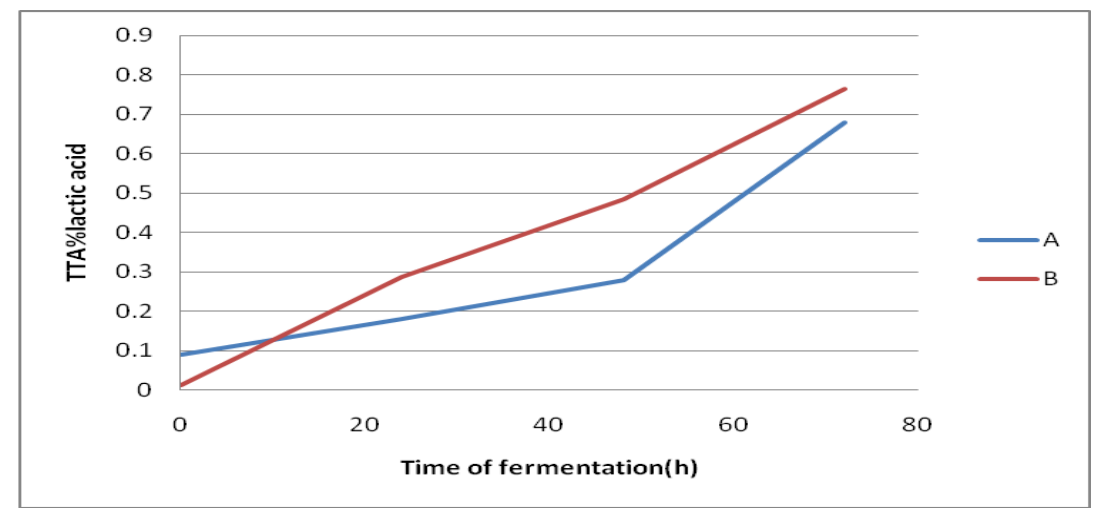

Key: A= Co-Fermented Bitter Yam/ Cowpea 70:30g, B= Co-Fermented Bitter Yam/ Cowpea 60:40g 
Fig.2 Comparable Bostwick Consistency of Co-Fermented Bitter Yam/Cowpea and Unfermented Mixtures in Different Ratios

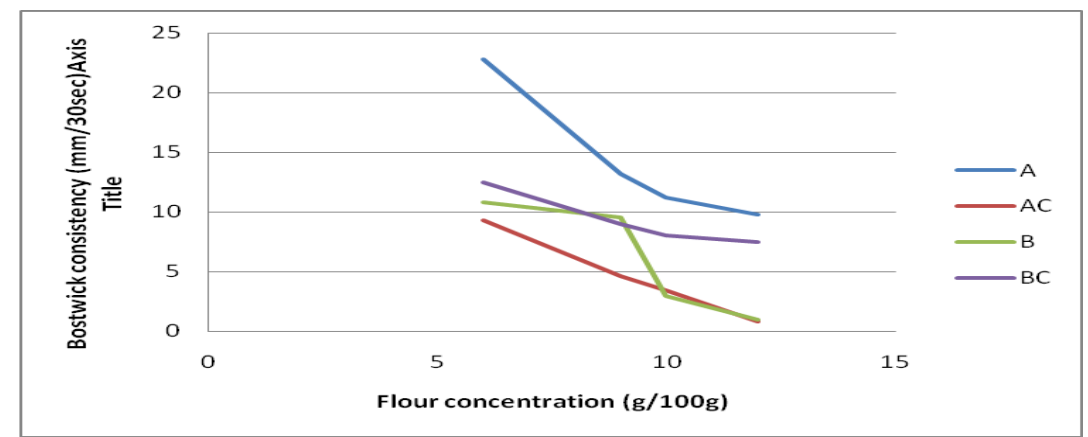

KEY: A= Bitter Yam / Cowpea 70:30, B=Bitter Yam / Cowpea 60:40, C= Unfermented Bitter yam/Cowpea 70:30, D= Unfermented Bitter Yam/ Cowpea 60:40

Sodium: Together with chloride sodium functions in maintenance of extracellular fluids (ECF) and blood pressure. Cofermentation appeared to decrease sodium content of $\mathrm{A}$ and $\mathrm{B}$ than the unfermented and D samples. Sodium is the major action of fluids in the body cells. Sodium and potassium ratio of 0.60 is recommended; in this study, the ratio in sample A was 0.86 , 0.70 in B, sample C was 0.49 and 0.85 in D. The sodium values of samples in this work for sample A is comparable to $117 \mathrm{mg} / \mathrm{d}$ for 6-8mo infants on average breast milk intake; B comparable to $334 \mathrm{mg} / \mathrm{d}$ for $11-23 \mathrm{mo}$ on high breast milk intake; $\mathrm{C}$ value was comparable to $199 \mathrm{mg} / \mathrm{d}$ for 6-8 mo on average breast milk intake while value of sample D was higher than recommended value of sodium needs from complementary foods for ages 6-23months. Co fermentation reduced calcium, potassium, zinc and manganese but increased iron in all the samples of this study.

\section{Mineral Safety Index}

Some minerals especially when taken in large amount can result in abnormally high levels $\mathrm{n}$ the blood. Table 3. Showed the calculated mineral safety index (MSI) of the samples according to MSI requirements for Infants. Minus values means overshooting than recommended value. If the MSI is less than recommended, then there will not be any minus (Whitney et al. 2009). For MSI iron, samples A and B had comparable values to the recommended MSI values while $\mathrm{C}$ and D had significantly $(\mathrm{p}<, 0.05)$ lower values. Sample D had higher Na value than recommended MSI while sample $\mathrm{C}$ had comparable value.

The $\mathrm{Zn}$ value was higher in sample $\mathrm{B}$ while the values in the remaining samples were lower than MSI recommended value.

In conclusion, from this research work, it may be concluded that infant complementary food of nutritive quality can be prepared using co-fermentation process, to meet the macro nutritional needs of infants and babies-Fortification.

\section{Recommendation}

Various indigenous and under-utilized tubers and legumes should be co-fermented for extensive use as infant complementary food. However, certain aspects like the digestibility and bio-availability of macronutrients as well as micronutrients in the samples needs further study to know whether the prepared food needs further modification with or without. 


\section{References}

Adeyeye, E.I., Falaye, F.J. 2004. Mineral Components for Health from Animal Sources. Pakistan J. Sci. Industrial Res., 47(6): 471-477.

Aderiye, B.I., Ogunjobi, A.A. 1998. Fermentation of yam: microbiology and sensory evaluation of cooked fermented yam tissues. Pl. Foods for Human Nutri., 52(1): 49-54.

Ahmed, M. 2005. Effect of processing treatment on acceptability of soybean based weaning food. M. S. thesis, Bangladesh Agricultural University, Ymensingh.

Ahmad, S. 2001. Development and evaluation of deep-fried carrot chips as a source of vitamin A ETD Collection for University of Nebraska Linncoln. diitalcommons un/edu/dissertations /AA/3034392.

Akingbala, J.O., Rooney, L.W., Faubion, J.M. 1981. A laboratory procedure for the preparation of 'ogi' - a Nigerian fermented Food. J. Food Sci., 43: 1523-1526.

doi.wiley.com/10.1111/j1365-

$26211981+b 0214 x$

AOAC. 2005. Official methods of analysis of the Association of Official Analytical Chemists. $17^{\text {th }}$ edn., chapter 50 pp.18 AOAC, VA, USA.

Alice, J. 2010. An Economic Analysis of Cowpea Production among Women Farmers in Askira-Uba, Borno State. African J. General Agri., 6(1): 8.

CODEX 1991. Guidelines For Formulated Supplement For Older Adults And Young Children Adapted By Codex Alimentarius Commission At Its $19^{\text {th }}$ Session 1991 Cac/Glo8-1991.

Davis, D.W., Oelke, E.A., Oplinger, E.S., Hanson, C.V., Putnam, D.H. 2013. Alternative Field Crop Manual.
Department of Horticultural Science, Agronomy and Plant Genetics: Center for Alternative Plant and Animal Products Minnesota Extension Service, University of Minnesota, U.S.A.

Degras, L. 1993. The Yam: A Tropical Root Crop. 2nd Edn. Macmillan Press, London. pp: 121-138.

Della, B., Rodriguez-Amaya. 2009. Effect of processing and storage on food Carotenoid Sight and life Newsletter $3 / 2002$

www.mostproject.org/PDF/30\%20200 2\%20SLpdf.

Delvin, T.M. 2006. Textbook of Biochemistry with Clinical Correlations. $6^{\text {th }}$ edn. Wiley-Liss (AJohn Wiley and Sons Inc.Publication), Hoboken, New Jersey, pp; 1093-1095.ISBN10:0470109890

Elemo, G.N., Elemo, B.N., Okabor, J.N.C. 2008. Preparation and nutritional Energy Density of Complementary Foods on total Energy intakes.

Golden, M. 2009. Nutrient Requirements of Moderately Malnourished Populations of Children. Food Nutr. Bull.

Ihekoronye, A.I., Ngoddy, P.O. 1985. Integrated Food Science and Technology. Macmillan Publishers pp.129-130. Microbiological and Nutrition Quality of Retail and Laboratory 'ikpan' (mushroommeloncake) a local snackInternet J. Nutri. and Wellness, (8): 2.

IITA. 2004. International Institute of Tropical Agriculture, Summary proceedings of the stakeholder meeting for the project on Yam. Research review.

Ismail, F.A., Galal, F.S., El-Atawy, Y.S., Bakry, A.A. 2000. Chemical and physical characteristics of weaning foods prepared from cereals and 
legumes. Egyptian J. Agri. Res., 78(1): 293-308.

Livnyl, O., Reifen, R., Levy, I., Madar, zFaulks, R., Southon, S., Schartz, B. 2003. $\beta$-carotene bioavailability from differently processed carrot meals in human ileostomy volunteers. Eur $J$. Nutr: vol.42 (6) pp338-345\}. www/springerlink.com/index/WY2M MVH8GXFDYP2Qpdf.Assessed $8^{\text {th }}$ Feb 2009

Medosa, G.N., Mbome, I.L., Agbor-Egbe, T., Mbofung, G.M.F. 2005. Physicochemical changes occurring during post-harvest hardening of trifoliate yam (Dioscorea dumetorum). Food Chem., 90: 597601.

McClaren, D.S., Frigg, M. 2001. Sight and Life Manual on vitamin A Deficiency Disorders. 2nd Edn. Task Force Sight and Life, Bessel, Switzerland, pp. 9-19, 21-36. 79-86, 117-118.

Modu, S., Laminu, H.H., Abba, S.F. 2010. Evaluation of the nutritional value of a composite meal prepared from pearl millet and cowpea. Bayero J. Pure Appl. Sci., 3(1): 164-168.

Mohammad, Y.J.B. 2008. Formulation of weaning food from sorghum and pigeon pea. M. S. thesis, Khartoum University, Sudan.

Nieman, D.C., Butterworth, D.E., Nieman, C.N. 2002. Nutrition. Revised First Edition pp 273-308. Publisher wim.C. Brown Publisher.

Ojofeitimi, E.O. 2007. Malnutrition and Approaches to Improving the Nutritional Status of Children in Low Income Settings. Department of Community Health, College of Health Sciences, Obafemi Awolowo University, Ile Ife, Osun State, Nigeria.

Oyarekua, M.A. 2011. Evaluation of the nutritional and microbiological status of co-fermented cereals/cowpea 'OGI'. Agri. Biol. J. North America, (1): pp. 61-73.

Oyarekua, M.A. 2013. Effect of cofermentation on Nutritive quality and pasting properties of Maize/cowpea/sweet potato as Complementary Food. African $J$. Food, Agri., Nutri. Development, (AJFAND), Vol. 13. No1. pp. 71717191.

Oyarekua, M.A. 2015. Comparative studies of co-fermented maize/pigeon pea and maize/mucuna as infants complementary foods. Wudpecker $J$. Food Technol., 1(1): 1-8.

Oyarekua, M.A. 2009. Co-fermentation of cassava/cowpea/carrot to produce infant complementary food of improved nutritive quality. Asian $J$. Clin. Nutri., 1(3): 120-130, ISSN 1992-1470.

Oyarekua, M.A., Bankefa, E.O. 2015. The Effect of Cooking and Fermentation on the Functional and Nutritional Properties of Walnut and Maize. Int. J. Nutri. Food Sci., 4(3): 332-342.

Oyewole, O.B., Odunfa, S.A. 1990. Cofermentation of cassava with Legumes for protein rich fermented cassava fufu.wwwoyewoleunaab.net/publications.htm.

PAG. 1971. Protein Advisory Group of the United Nations, PAG guideline no.8, protein-rich mixtures for use as weaning foods. New York: FAD/WHO/UNICEF.

Paredes-López, O., Harry, G.I. 1988. Food biotechnology review: traditional solid-state fermentations of plant raw materials - application, nutritional significance and future prospects. Crit. Rev. Food Sci. Nutri., (27): 159187.

http://dx.doi.org/10.1080/1040839880 9527483. 
Rodriguez-Amaya, D.B., Kimura, M. 2004. Harvest Plus Handbook for Carotenoid Analysis.

Harvest Plus Technical Monogram 2. Washington DC and Cali: International Food Policy Research Institute (IFPRI) and International Center for Tropical Agriculture (CIAT) pp. 127-135.

Subharno, D., West, C.E., Muhalil, K.D., Hautvast, J.G.A.G. 1993. Supplementation with vitamin A and iron for nutritional anemia in pregnant women in west Java, Indonesia. Lancet, 342: 1325-1328.

Sefa-Dedeh, S.K., Sakyi-Dawson. 2001. Effect of Drying Method, Packageing Material and Storage on the Quality of Cowpea-based Weaning Foods. Paper Presented at the Annual Meeting of the Institute of Technology, New Orleans, USA, pp. 25-28.

Soetan, K.O., Oyewole, O.E. 2009. The need for adequate processing to reduce the anti- nutritional factors in plants used for human food and animal feeds- A Review. Afr. J. Food Sci., 3(9): 123-132.

Whitney, E.N., Hamilton, E.M.N., Rolfes, S.R. 1990. Understanding Nutrition. Pp. 430-453. Ppbl. West Publishing Company. St. Paul, N. York, Los Angeles and Fransisco

WHO/UNICEF. University of California/Davies and ORSTOM, WHO, NUT/96-9.

WHO's Global Strategy for Infant and Young Child Feeding (available at http://whqlibdoc.who.int/publications/ 2003/9241562218.pdf, Accessed April 5 2012)

World Health Organization. 1998. Complementary Feeding of Infants and Young Children. Report of a Technical Consultation Supported by WHO/UNICEF. University of California/Davies and ORSTOM, WHO, NUT/96-9.

How to cite this article:

Oyarekua Mojisola Adenike. 2016. Effect of Co Fermentation on Nutritional and Sensory Evaluation of Bitter Yam and Cowpea as Complementary Food. Int.J.Curr.Microbiol.App.Sci. 5(4): 267-278. doi: http://dx.doi.org/10.20546/ijcmas.2016.504.031 